\title{
‘THIRD GENERATION’ RIGHTS: IS THERE ROOM FOR HYBRID CONSTRUCTS WITHIN INTERNATIONAL HUMAN RIGHTS LAW?
}

\author{
Rosa Freedman ${ }^{*}$
}

\section{Keywords}

Human rights, Third Generation Rights, hybridity

\begin{abstract}
Human rights, which are by nature dynamic and constantly evolving, need to accommodate new rights, just as each generation should contribute to their evolution, in keeping with the aspirations and values of the time. ${ }^{1}$
\end{abstract}

\section{Introduction}

International human rights law is not static; evolution of human rights is at the heart of the system. United Nations human rights institutions' mandates require them to develop, as well as protect and promote, rights. Since the beginning of the modern human rights era, individual rights and the human rights system have constantly evolved. Initially, ideological battles centred upon the tensions between and ideological divisions underpinning Civil and Political Rights and Economic, Social and Cultural Rights. The next significant evolution occurred with the advent of Third Generation Rights, also known as 'Collective Rights' or 'Peoples Rights.' Those rights were rooted in post-colonial discourses, drawing

\footnotetext{
Dr Rosa Freedman is a Lecturer at Birmingham Law School, University of Birmingham. Rosa obtained a PhD, LLM (Public International Law) and LLB (hons) from University of London. She is the author of The United Nations Human Rights Council: A Critique and Early Assessment (Routledge, 2013). A member of the English Bar, she provides legal research to various human rights NGOs and is a regular contributor to online media, including The Guardian, Huffington Post and UK Human Rights Blog. The author is grateful to James Crawford, Graham Gee and Nicolas Lemay-Hebert for comments on earlier drafts of this article. She can be contacted at: $<$ r.a.freedman@bham.ac.uk>.

1 HRC $12^{\text {th }}$ Session, Report of the Independent Expert on International Solidarity, UN Doc A./HRC/12/27, 22 July 2009, para. 11.

2 As distinguished from individuals' rights, cf. B H Weston, 'Human Rights' (1984) 6(3) Human Rights Quarterly, 257.
} 
on the newly decolonised states' mosaic of imperial experiences. The most recent development is the second wave of Third Generation Rights. Unlike the first wave, these newer rights cannot be understood as a reaction to colonialism; instead, the concept of 'hybridity' can help explain the ideologies upon which they are based, the processes through which they are created as well as the rights themselves.

Hybridity occurs where there is resistance to domination that occurs through colonisation, occupation, intervention, or other power imbalances. Resistance comes from the 'local', used not in the parochial sense but to mean the space created 'in which everyday practices are used'. The local may exist at the national, transnational or global levels. ${ }^{3}$ Hybridity, then, is not based upon the merging of two different, binary entities; rather, it occurs through the meeting of those entities and the processes of resistance and adaptation on both sides. What emerges is not a mixing of the two, but a third entity that challenges the dominant-substantively or ideologically-while simultaneously incorporating norms and values from both. It goes beyond 'mimicry' or repetition of the dominant order, instead becoming 'an uncertainty which fixes the colonial subject as a partial presence. ${ }^{4}$ This lens moves the discourse and understanding away from 'unhelpful binaries' and 'towards thinking about the multiplicity of outcomes that might occur when two entities meet and interact. ${ }^{5}$ The interaction is key, particularly the different level of resistance within each relationship resulting in challenges to the dominant framework that necessarily incorporate ideas and norms from the local and external entities.

Hybridity is a relatively underdeveloped area within legal scholarship. Throughout this article, I develop and apply a framework for understanding hybridity and its role and impact within the international arena. The framework consists of three interconnected elements. Firstly, hybridity is a theory that enables understanding of identities, providing a lens through which cultures may be viewed. Hybridity, or hybridisation, is also a process through which identities and cultures are forged, with a 'multiplicity of outcomes' that depend on 'complex and context-specific realities. ${ }^{6}$ Traditionally, that process is viewed as occurring

\footnotetext{
3 O Richmond \& A Mitchell, 'Introduction' in O Richmond \& A Mitchell (eds), Hybrid Forms of Peace: From everyday agency to post-liberalism (2012) 11.

${ }^{4}$ H K Bhabha, The Location of Culture (1994) 123.

${ }^{5}$ J H Peterson, 'A Conceptual Unpacking Of Hybridity: Accounting For Notions Of Power, Politics And Progress In Analyses Of Aid-Driven Interfaces' (2012) 7(2) Journal of Peacebuilding \& Development 9, 12.

${ }^{6}$ Ibid.
} 
within postcolonial, or other formerly occupied or dominated, societies. Yet, the process of constructing identities, ideologies and objectives also takes place within the international arena. Lastly, hybridity is an entity in terms of the constructs that emerge based on the theory and resulting from the process. All three elements are integral for understanding international human rights law's current evolutionary cycle.

The impact of non-Western constructs on international law has traditionally been explored through post-Marxist discourses, particularly post-colonialism. Hybridity is a relatively new lens through which these issues can be viewed. The theory has roots within classics and the humanities, but has only recently been applied within social sciences and legal frameworks, albeit using case studies from the local, national or regional level. It is clear that ideological, political, and legal discourses are crucial for understanding current changes to, or attempts to change, international human rights law. The shift in global power and politics has underscored the need to represent hybrid constructs within international law. The international legal system is moving in this direction, with peace-building and interventions, for example, beginning to represent heterogeneous norms that incorporate African, ${ }^{7}$ Asian $^{8}$ and Islamic ${ }^{9}$ ideologies and values on responsibilities, communities and social justice.

Significant literature has explored the ideologies underpinning international human rights law, particularly in relation to the three categories, or 'generations', of rights. Much has also been written on the expansion of human rights and the resultant impact on the system as a whole. However, legal scholarship is yet to address systematically the recent second wave of Third Generation Rights. The practical effect is being felt across the international human rights system, with time and resources being allocated to discussions, declarations, resolutions and Special Procedures mandates aimed at developing these newer rights. Those developments are not being examined or discussed within the academy, let alone analysed from an interdisciplinary perspective. There is an obvious need to understand the rights themselves, the reasons that they are being promoted, and the ideologies upon which they are built.

Previous legal scholarship on Third Generation Rights confined discussions

\footnotetext{
See e.g. C Heyns, 'The African Regional Human Rights System: The African Charter' (2004) 108 Penn State Law Review 679.

${ }^{8}$ See e.g. B Kausikan, 'Asia's Different Standard' (1993) 92 Foreign Policy 24.

9 See e.g. J Morgan-Foster, "Third Generation Rights: What Islamic Law Can Teach the International Human Rights Movement' (2005) 8 Yale Human Rights and Development Law Journal 67.
} 
to substantive rights stemming from post-colonialism. ${ }^{10}$ The recent increase of this category of rights, and the methods used to introduce them into international human rights law, necessitates new research and analysis. If Third Generation Rights are a method for expanding international human rights law, a thorough, interdisciplinary analysis needs to take place. Another explanation is that states promoting Third Generation Rights are attempting to dilute this area of law. That aim would stem from political objectives unrelated to protecting and promoting human rights. If Third Generation Rights are being used to undermine the resources available for traditional rights, and to muddy the water of what constitutes a right, then it is imperative to address that issue.

This article has three main aims: first, to develop a framework for understanding hybridity at the international level; second, to explore the ways in which hybridity operates within the international arena, specifically on international human rights law; and third, to address the current literature gap on the new wave of Third Generation Rights. By advancing the theoretical model, the article develops the ways in which hybridity is used to understand practical developments at the international level. It widens the debate by drawing on a broad range of hybridity literature from across various disciplines in order to produce theories that are then applied to new Third Generation Rights. The article also demonstrates the pressing need to understand how hybrid rights are impacting upon the international human rights system.

\section{Hybridity}

Hybridity occurs within what Bhabha calls the "Third Space'11 that exists between the dominant and the dominated, the coloniser and the colonised. That space may be a metaphor or a place; it is the 'contact zone"12 produced by the colonial, or other power-imbalanced, relationship. An alternative both to post-colonial discourses and globalisation, ${ }^{13}$ to cultural relativism and universalism, hybridity goes beyond the binaries that exist within those competing theories and instead

\footnotetext{
${ }^{10}$ See e.g. P Alston, 'A Third Generation of Solidarity Rights: Progressive Development or Obfuscation of International Human Rights Law?' (1982) 29 Netherlands International Law Review 307; G Triggs, 'The Rights of "Peoples" and Individual Rights: Conflict or Harmony?', in J Crawford (ed), The Rights Of Peoples (1988) 141.

${ }^{11}$ Bhabha, above n 4; R C Young, Colonial Desire: Hybridity in Theory, Culture and Race (1995) 37.

${ }^{12}$ B Ashcroft, G Griffiths \& H Tiffin, Post-Colonial Studies: The Key Concepts (2000) 118.

${ }^{13}$ See generally A J Paolini, Navigating Modernity: Postcolonialism, Identity and International Relations (1999), particularly the methodology contained within 5-8.
} 
explores the relationship between the two entities and 'the multiplicity of outcomes that might occur. ${ }^{14}$ Instead of focusing on the 'fact' of post-colonialism, hybridity results from the 'markedly unbalanced relationship' between the dominated and the dominant. ${ }^{15}$ It recognises that intertwining between the local and the foreign, the dominant and the weak, results in construction of a third identity that does more than simply mix the components. Hybridity is 'a site for transformation and change where fixed identities based on essentialisms are called into question. ${ }^{16}$ Identities are forged based on ideologies, customs, values and norms emanating from, but not exclusive to, both entities as well as the intertwining of heritages. The hybrid identity is more than the sum total of its parts-it is a wholly new construct created through the interaction between two binaries and the resistance that occurs during that meeting.

Universalists, often advancing a globalisation theory, 'assume an increasing homogenization of the world' ${ }^{\prime}{ }^{17}$ while cultural relativists, frequently relying on post-colonial discourses, 'posit notions of difference and resistance ${ }^{18}$ in the relationships between the global North and South. Hybridity within international and transnational relationships is viewed through a markedly different lens to that previously adopted by scholars of political science, post-colonialism, classics and law who examine relationships between dominant and dominated actors. Rather than viewing interactions as top-down impositions, hybridity theories are used to understand and interpret relationships that occur at the 'local' level. ${ }^{19}$ This includes, but is not limited to, the relationship between actors, ideologies and institutions. It examines the impact that norms and cultures have on national, regional and international systems. Typically, this occurs through power relationships. Although hybridity has been used primarily in relation to case studies from the national level, such as state-building and peace-building,

\footnotetext{
14 Peterson, above n 5, 12.

${ }^{15}$ J Kurotti \& J Nyman, 'Introduction: Hybridity Today', in J Kuortti \& J Nyman (eds), Reconstructing Hybridity: Post-Colonial Studies in Transition (2007) 2.

${ }^{16}$ Ibid, 3.

${ }^{17}$ Paolini, above $\mathrm{n} 13,6$.

${ }^{18}$ Ibid, 5.

${ }^{19}$ Richmond \& Mitchell redefine the word 'local' as referring to 'the terrain in which everyday practices are used within (and in order to create) a local space. In this sense, the local is not to be essentialized or parochialized; it refers to a space that is, in a sense, transversal, transnational and even global, or at least a feature of most human societies. Whilst the local is the realm in which everyday activities emerge and unfold, a locale is a unique local space conditioned by the everyday traditions, practices, values, identities and moral, ethical or "radical" (i.e., root) sources of the groups in question.' Richmond \& Mitchell, above n 3, 11.
} 
recent attempts have been made to apply the theory to international developments. Understanding hybridity enables scholars to explore national, regional and international developments through an alternative lens-one that seeks to avoid polarising and being polarised.

As a theory, hybridity provides a lens through which ideologies, norms and values may be viewed. Theories may also be an input within the international arena. This occurs when governments, or their delegates, demonstrate that their positions have been informed by the hybridity theory. That may occur within regional groups and political blocs, when collective aims and ideologies are constructed, or may take place within international institutions. Post-colonialist theories frequently have been heard at UN human rights bodies. Abebe, the First Secretary at the Permanent Mission of Ethiopia in Geneva, relies upon and adopts post-colonial discourses in his scholarship. ${ }^{20}$ Those views are then incorporated into statements made on behalf of his government. Other statements delivered by state delegates may be couched in the language of postcolonial discourses rather than relying directly on those theories: China has referred to human rights at as a 'neo-colonial tool of oppression,', 21 for example, while Cuba complained of 'imperialism' within UN human rights bodies. ${ }^{22}$ Theories, then, do not operate only at the abstract level but become inputs within the international arena. Discourses based on hybridity theories are beginning to be adopted within oral statements made within, and reports given to, the UN Human Rights Council. As will be demonstrated with reference to the development of second wave Third Generation Rights, hybridity theories are present within the language of resolutions, decisions and reports on the new rights as well as discussions within UN bodies. $^{23}$

As a process, hybridity occurs within the Third Space-something that is still being defined and applied within post-colonial studies and across a broad range of disciplines. ${ }^{24}$ Bhabha's 'Third Space' is a metaphor for the meeting of cultures-where the colonised and coloniser intertwine and from where the distinct hybrid identity emerges. ${ }^{25}$ Bhabha, at times, also used the Third Space as

\footnotetext{
${ }^{20}$ See generally A M Abebe, 'Of shaming and bargaining: African states and the universal periodic review of the United Nations Human Rights Council' (2009) 9(1) Human Rights LR 1.

${ }^{21}$ P Alston, 'Reconceiving the UN Human Rights Regime: Challenges Confronting the New UN Human Rights Council’ (2006) 7 Melbourne JIL 205-206.

${ }^{22}$ For Cuban delegate's oral remarks, see CHR, 'Commission on Human Rights opens Sixty-First Session', UN Doc HR/CN/1107, 14 March 2005.

${ }^{23}$ See section 4 (below).

${ }^{24}$ See generally K Ikas \& G Wagner (eds), Communicating in The Third Space (2009).

${ }^{25}$ Bhabha, above n 4, 218.
} 
a place, although those uses were confined to the local, predominantly national, level. Traditionally, that Third Space is viewed as existing within postcolonial societies. Yet, the construction of identities, ideologies and objectives also takes place within the international arena. The Third Space may be mapped onto the international level both as metaphor and as a place. International institutions, in terms of formal bodies and the place that they provide for like-minded states to meet within regional groups and political blocs, provide a physical Third Space for the construction of hybrid norms, values and ideologies. Hybridity as a process may also be viewed as the way inputs are converted into outputs. Within the international human rights system, the conversion process takes place through intergovernmental negotiations and through coalition-building to form a majority for voting purposes. ${ }^{26}$ Both of those conversion processes require inputs to be hybridised, for countries to set out their ideologies, which meet and resist one another, in order to forge new constructions that will be acceptable to the negotiating states.

As an entity, hybridity may exist within tangible matters including art, literature, language and, indeed, law. At the international level, hybrid entities based on theories and processes include: certain international criminal courts and tribunals; ${ }^{27}$ aspects of some international instruments; and the second wave of Third Generation Rights. ${ }^{28}$ In many respects, it is easier to demonstrate hybridity as an entity owing to its tangible nature, although this third element is not of any greater or lesser importance than hybridity as a theory or as a process.

All three elements-theory, process and entity-are necessary for understanding how hybridity operates at the international level. The elements interconnect and interact with one another, demonstrating that hybridity cannot solely be used as an abstract concept or as a lens through which matters are viewed. The theory of hybridity is at a relatively early stage of its development in terms of when and how it is applied by legal scholars and political scientists. Its importance has been recognised by scholars such as Said, who insists that hybridity is 'the essential idea for the revolutionary realities today' ${ }^{29}$ Revolutions occur throughout the world, at the local, national, regional and international lev-

\footnotetext{
${ }^{26}$ See generally R Freedman, The United Nations Human Rights Council: A critique and early assessment (2013) 114-115.

${ }^{27}$ Examples include the Special Court for Sierra Leone and the Extraordinary Chambers in the Courts of Cambodia.

${ }^{28}$ Examples include the right to international solidarity and the right to a democratic and equitable international order.

${ }^{29}$ E Said, Culture and Imperialism (1993) 317.
} 
els. Events within the international arena demonstrate a current revolution regarding the Global South moving away from postcolonial discourses and towards ensuring that their own, heterogeneous, norms, values and identities are recognised within international law.

Although first developed within postcolonial studies, ${ }^{30}$ with many theorists from that discipline insisting that hybridity only applies to colonial and postcolonial relationships, ${ }^{31}$ there is increasing movement towards recognising hybridity's interdisciplinary roots and application. Political scientists have adopted and extended that analysis to include all cultures and ideologies. Whereas previous imposition of Western constructs occurred without systematic analysis about the impact on indigenous populations, there has been growing recognition of the need to assess the effect at the local level. ${ }^{32}$ Political scientists apply hybridity to issues such as peace-building, ${ }^{33}$ interventions, ${ }^{34}$ state-building, ${ }^{35}$ and international criminal courts. ${ }^{36}$ Those are all case studies that demonstrate that nothing is purely local or purely international. ${ }^{37}$ Hybridity, then, is raised within the context of specific circumstances, with theorists combining individual case studies to draw broader conclusions, including about how events at the national and even regional levels inform the international discourse. Hybridity research within legal scholarship follows similar patterns, using events at the national or regional levels to illustrate and inform research findings. Applying the framework set out above to case studies at the international level, I shall demonstrate how the three elements, combined, can be used to understand how hybridity operates within, and impacts upon, the international arena.

Throughout modern international law, many states were unable to present their norms and ideologies within international institutions. ${ }^{38}$ Since the end of the Cold War, and increasingly since the turn of the Millennium, states from the

\footnotetext{
${ }^{30}$ See e.g. Bhabha, above n 4; Young, above n 11.

${ }^{31}$ See generally Kuortti \& Nyman, above n 15, 2

${ }^{32}$ See generally R MacGinty, International Peacebuilding and Local Resistance: Hybrid forms of peace (2011).

${ }^{33}$ See e.g. Richmond \& Mitchell, above $\mathrm{n} 3$.

${ }^{34}$ See e.g. R MacGinty, 'Hybrid Peace: The Interaction Between Top-Down and Bottom-Up Peace' (2010) 41(4) Security Dialogue 391.

${ }^{35}$ See e.g. K P Clements, et al, 'State Building Reconsidered: The Role of Hybridity in the Formation of Political Order' (2007) 59(1) Political Science 45.

${ }^{36}$ See e.g. O Martin-Ortega \& J Herman, 'Hybrid Tribunals: Interaction and Resistance in Bosnia and Herzegovina and Cambodia', in Richmond \& Mitchell, above n 3, 73.

${ }^{37}$ See generally MacGinty, above $\mathrm{n} 33$.

${ }^{38}$ See generally A Anghie, Imperialism, Sovereignty and the Making of International Law (2004).
} 
Non-Aligned Movement (NAM) and the Organisation of Islamic Cooperation (OIC), alongside regional allies from Africa, Asia and Latin America, have sought greater representation of their cultures. ${ }^{39}$ Hybridity is a key method by which African states, and more generally the "Third World', ${ }^{40}$ are able to move away from their former consignment to the margins within the international arena. Rather than the developing world being restricted to postcolonial discourses at the international level, and thus promoting ideologies formed as a direct response to colonial experiences, those states, groups and blocs are now promoting hybrid constructs that represent national ideologies based on identities forged within Bhabha's 'Third Space'. With the increase in power and strength of developing countries and former colonies, there has been increasing movement away from postcolonial discourses and towards promoting hybrid constructs. Those ideas are beginning to affect the work of international human rights bodies, financial institutions, courts and tribunals.

\section{Hybridity and international human rights law}

International human rights law provides the perfect canvas from which to draw broader conclusions about hybridity's impact on international law. The most recent wave or category of human rights are predominantly created and promoted by states from the Global South, particularly from Africa and Asia. Those states' national ideologies, norms and cultures focus on responsibilities rather than rights ${ }^{41}$-differences clearly illustrated when contrasting the African and European regional human rights treaties and mechanisms. ${ }^{42}$ Those countries' use of the human rights system, with its traditional individual-centred focus, is a stark example of the intertwining of national cultures and norms with the dominant, Western mechanisms and framework. By engaging with the system of 'rights', and by seeking to promote their own objectives within that framework, states from the Global South are using hybridity theories to inform their actions and to create processes and constructs that both meet and challenge the dominant ideology.

\footnotetext{
${ }^{39}$ See generally M Nowak et al, 'UN Human Rights Council in Crisis-Proposals to Enhance the Effectiveness of the Council', in W Benedek et al (eds), European Yearbook on Human Rights (2011) 41, 58-59.

${ }^{40}$ Paolini, above n $13,4$.

${ }^{41}$ See generally B Obinna Okere, "The Protection of Human Rights and the African Charter on Human and People's Rights: A Comparative Analysis with the European and American Systems', (1984) 6(2) Human Rights Quarterly 141; Kausikan, above n 8.

${ }^{42}$ See generally Obinna Okere, above $n 41$.
} 
Collective rights are often cited as examples of hybridity within international law; yet those rights were a direct response to colonialism rather than representing states' own values. They introduced a third category of human rights that complemented, rather than challenged, Civil and Political Rights and Economic, Social and Cultural Rights. The first wave of Third Generation Rights has recently been followed by a second wave of 'rights' rooted in hybrid constructs rather than postcolonial discourses. These newer rights are sometimes in direct conflict with existing ways of understanding human rights. Rights are hybrid not only in terms of their substance, subjects and scope, but also in terms of the areas that they seek to bring into the human rights system. As such, it is necessary to examine the latest evolution of human rights in order to determine whetherdespite the clear need to enable hybridity as a process-there is room for these constructs within international human rights law.

In terms of the substance of human rights, dominant ideologies stemmed initially from the West (Civil and Political Rights), quickly followed by Soviet notions of rights (Economic, Social and Cultural Rights). From the Universal Declaration, in 1948, dominant ideologies have been at the fore in international human rights law's development. ${ }^{43}$ Until recently, decolonised and developing states, alongside allies from the Non-Aligned Movement, ${ }^{44}$ have promoted a 'Third Generation' of rights. ${ }^{45}$ The first wave of Third Generation Rights focused on ensuring rights directly stemming from colonial experiences-most notably rights to self-determination, development and permanent sovereignty over resources. ${ }^{46}$ Those rights are rooted in traditional postcolonial discourses that oppose imperialism and further an 'anticolonial nationalism.47 The Fanonian Framework, for example, insists on resistance and rejection of the dominant imperialist-Western-culture, language and identity, amongst others, in order to realise decolonised states' national interests. ${ }^{48}$

Current legal, political and ideological battles at the UN, where states are seeking to impact and shape international human rights law, demonstrate that

\footnotetext{
${ }^{43}$ GA Res. 217A (III), 10 December 1984, 'Universal Declaration of Human Rights'.

${ }^{44}$ NAM developed from the Asian-African Conference, a political gathering held in Bandung, Indonesia, in April 1955. The conference was convened in part due to frustration by many newly independent countries unable to secure UN membership due to Cold War politics. The two then-superpowers refused to admit states seen as belonging to the other camp.

${ }^{45}$ See generally B Algan, 'Rethinking “Third Generation” Human Rights', 2004 (1(1) Ankara Law Review 121.

${ }^{46}$ See e.g. Weston, above $\mathrm{n} 2$.

${ }^{47}$ See generally A Memmi, The Colonizer and the Colonized (1957).

${ }^{48}$ See generally F Fanon, Black Skin, White Masks (1952); F Fanon, The Wretched of the Earth (1968).
} 
traditional postcolonial discourses are being complemented by, or replaced with, hybridity. Those battles are following a markedly different pattern than occurred during the creation of collective rights. Hybridity is focused on a less oppositional stance than traditional post-colonial discourses; ${ }^{49}$ it recognises a more 'syncretic dynamic' between the coloniser and the colonised, or the dominant and the dominated. ${ }^{50}$ It is a process of 'engagement with' rather than 'opposition to'. That is clearly seen in the way that states from the Global South are using the human rights system, based on the dominant ideology, to further their own constructs and ideologies. The first wave of Third Generation Rights required the previously individual-centred system to change radically in order to include collective rights. Hybrid rights are less oppositional, because they utilise the existing human rights framework in order to promote norms not previously incorporated within that system.

Whereas rights within each of the three traditional categories-Civil and Political; Economic, Social and Cultural; and Collective-largely conform to their respective ideologies, hybrid rights draw upon different norms and values depending on the states involved with the input, conversion and output processes. The theory, process and entity within each of these new rights are different owing to the actors, ideologies, relationships and resistance varying within every context. Hybridity provides a 'key analytical tool' for examining each right because it 'allows for a heightened understanding of differences' between each case study. 51

The impact of hybridity, as theory, process and entity, at the international level depends on two distinct factors: (1) the impact of states' hybrid identities, created at the national level, within the international arena; and (2) the construction of hybrid identities through 'Third Space' fora within the international arena. States, particularly from Africa, Asia and Latin America, use political blocs and international institutions to further their own ideologies and objectives as well as to construct hybrid identities and aims at the international level. Political blocs and international institutions provide arenas within which states from the Global South can exercise collective power. ${ }^{52}$ Whereas such fora previously were used

\footnotetext{
${ }^{49}$ See e.g. H K Bhabha, 'Signs Taken for Wonders: Questions of Ambivalence and Authority Under a Tree Outside Delhi, May 1817', (1985) 12 Critical Inquiry 144, 152-153; G C Spivak, 'Subaltern Studies: Deconstructing Histiography' in R Guha (ed), Subaltern Studies IV: Writings on South Asian History and Society (1985) 5.

${ }^{50}$ Paolini, above n $13,54$.

${ }^{51}$ Peterson, above n 5, 12.

52 See e.g. E Heinze, 'Even Handedness and the Politics of Human Rights' (2008) 21 Harvard Human
} 
to unite behind postcolonial discourses, they are now utilised to create hybrid objectives that member states then collectively promote and support. Individually or in sub-groups, those same countries lack the power needed to challenge dominant states and ideologies. As a bloc, they are able to pursue collective aims. The hybrid constructs created within, and promoted by, political blocs reflect the need for collective aims, forged through the hybridity process within the international Third Space, in order to challenge dominant ideologies. The range of heterogeneous identities within such blocs can be seen in the older alliances of the Non-Aligned Movement and the Group of $77^{53}$ - whose allegiances originally stemmed from anti-imperialism and lack of alignment to the dominant powersas well as in the more recently created Organisation of Islamic Cooperation and G7+. ${ }^{54}$ All of those blocs span at least three of the five geographic regions, which enables formation of significant cross-regional alliances. Heterogeneity requires objectives to be forged through a hybridity process, resulting in hybrid constructs based on a mosaic of norms, cultures, values and experiences.

Movement away from post-colonialism and towards hybridity can be seen through non-Western and non-dominant states using political blocs to promote norms, values and cultures that go beyond the colonial experience. States that previously were dominated by the West have constructed new identities and ideologies based upon their own national identities and their collective and individual experiences within the international arena. The Non-Aligned Movement and the Organisation of Islamic Cooperation have been at the fore of promoting hybrid constructs of human rights based on non-Western and hybrid ideologies. The Organisation of Islamic Cooperation seeks to promote, amongst others, Islamic values and ideologies, ${ }^{55}$ while the Non-Aligned Movement largely focuses on collective objectives based on colonial experiences.

Hybrid human rights are based on hybrid identities, created through hybrid processes and containing hybrid constructs. They are promoted through 'soft law' methods that circumvent the need for custom or treaties to create

\section{Rights Journal 7.}

${ }^{53}$ G-77 was named at its creation in 1964, when 77 states jointly prepared for the UN Conference on Trade and Development. It worked in parallel with NAM, focusing on economic issues. On the relationship between NAM and G-77, see e.g. T G Weiss, What's Wrong with the United Nations and How to Fix It (2008), 49.

${ }^{54}$ G7+ was formed by a group of fragile and conflict-affected states in order to provide a mechanism for focusing on and engaging with peacebuilding and statebuilding. The heterogeneous group brings together states and international actors in order to facilitate development and capacity-building.

${ }^{55}$ Morgan-Foster, above $n 9$. 
international law. Those methods include political resolutions and decisions, including at the UN General Assembly and the Human Rights Council, through the creation of Special Procedures mandates to monitor and report on these 'rights', and through integration of these norms at the international level. State practice in this regard demonstrates the rise of hybridity and the movement away from post-colonial discourses within the international human rights arena. This brings with it a number of problems, not least: whether the human rights matrix is the most appropriate for dealing with many of these new 'rights'; the extent to which hybrid rights are being used by states with poor human rights records who seek to dilute or undermine the international human rights system; and whether new 'rights' ought to be developed where they are in clear tension, or even conflict, with traditional understandings of what constitutes a 'human right'. As such, and owing to the little available literature on these new, hybrid rights, it is necessary to explore whether there is room for hybrid constructs within international human rights law.

\section{Third Generation Rights}

'Third Generation' terminology on human rights was first articulated by Vasak in relation to collective rights, or those rights which could only be realised 'by the combined efforts of individuals, states, public and private associations, and the international community. ${ }^{56}$ Developed during the process of decolonisation, ${ }^{57}$ the first wave of Third Generation Rights can be seen as direct reactions to different aspects of colonialism. Rather than those rights being rooted in ideologies on human rights, they instead can trace their roots to the colonial experience. The advent of the right to self-determination being realised and implemented - that right being the oldest and most enshrined Third Generation Right $^{58}$ - clearly is a direct reaction to colonialism and occupation. A peoples' right to determine who governs over them does not represent a local or regional ideology; rather, it is a collective response to each country's experience of imperialism. The right to self-determination, then, represents neither a distinct

\footnotetext{
${ }^{56}$ See e.g. K Vasak 'Les différentes catégories des droits de l'homme' in T de Lapeyre \& K Vasak (eds), Les dimensions universelles des droits de l'homme (1990). Cf Donnelly, who insists that all human rights require collective action for realisation; J Donnelly, "The Theology of the Right to Development: A Reply to Alston' (1985) 15 California Western ILJ 521.

${ }^{57}$ K Vasak, The International Dimensions of Human Rights (1982).

${ }^{58}$ With roots in the US and French Declarations of Independence, as well as the UN Charter and core human rights treaties.
} 
ideology on human rights nor a hybrid construction of a third human rights identity, but a reaction to subjugation and oppression and thus falls under the post-colonial discourse. Similarly, the right to sovereignty over permanent resources is another response to the collective experience of colonialism and occupation, with the imperial powers having laid claim to the resources within states under their control. Again, this right represents a postcolonial discourse rather than having a distinct or hybrid ideology. States that had been formed in response to, and out of the ashes of, colonisation sought to assert rights to govern over themselves, as well as to economic and social development ${ }^{59}$ and to participate in and benefit from the common heritage of mankind. ${ }^{60}$ The first wave of Third Generation Rights was crucial to the decolonisation process, enabling newly self-governing states to assert collective rights to matters previously used by colonisers to subjugate and oppress those peoples. ${ }^{61}$

Recent events at UN bodies demonstrate that, in line with theories on hybridity, Third Generation Rights are now being extended beyond postcolonial discourses. That extension has occurred subsequent to many collective rights becoming enshrined and implemented at the international, regional and local levels and, perhaps more importantly, global politics shifting over the past two decades. Significant changes have occurred within the international arena, not least owing to: the end of the Cold War; the rise of Brazil, Russia, India and China (BRIC); economic and other powers shifting away from being the sole preserve of the West; and the increasing number of new political blocs representing alliances between non-Western states. Those changes have enabled decolonised and developing states to make their voices better heard at the international level. The second wave of Third Generation Rights includes development of rights to a democratic and equitable international order; to international solidarity; and to a clean and healthy environment. Rather than being a response to imperialism and based on post-colonial discourses, those rights are founded upon ideologies not previously represented within international human rights law.

The newer 'rights', at various stages in their development, reflect ideological perspectives of a range of states that were unable to make their voices heard during international human rights law's creation and development. ${ }^{62}$ However, the rights are not representative simply of a 'third' ideology, but rather of the

\footnotetext{
${ }^{59}$ See e.g. GA Res 41/128, 4 December 1986, 'Declaration on the Right to Development'.

${ }^{60}$ See e.g. Convention Concerning the Protection of World Cultural and Natural Heritage, 16 November 1972, 1037 UNTS 151.

${ }^{61}$ See generally Anghie, above $\mathrm{n} 38$.

${ }^{62}$ See generally Morgan-Foster, above n 9.
} 
many hybrid national identities and values constructed by states at the local level and then intertwined with one another through the hybridity process within the international arena. Each right represents the intertwining of a range of national and regional-local-ideologies as well as the broad range of those states' colonial experiences. It is that merging of ideologies and experiences that brings different hybrid constructs to the fore within each new right. Each ideological construct depends on the states that create and promote the right, their own human rights objectives and values, and their experiences of the dominant, Western human rights ideologies.

Hybridity can be seen in the ideologies underpinning these newer rights both in terms of the substance and beneficiaries of those rights. Hybrid rights build upon the idea of people's rights-incorporating collectiveness of people, nations and states. They also develop the subject matter of human rights. Although traditional rights touch upon areas linked to human rights, such as labour and social justice, they are aimed largely at human rights as traditionally understood. One interesting feature of the second wave of Third Generation Rights is that some of them bring into the human rights matrix matters that are linked to human rights but would traditionally have been dealt with through other institutions. In particular, issues that might better be addressed through environmental bodies or financial institutions are being viewed through a human rights prism. This may be owing to hybrid ideologies on human rights, with the use of Bhabha's 'Third Space' to construct new ways of thinking about what constitutes a 'human right' and whether such rights can exist within a vacuum. Another, more realist, perspective is that other institutions are less effective than those within the human rights matrix, and therefore states are using hybrid constructs to enable such matters to be brought within the human rights matrix.

Third Generation Rights seek to challenge the dominant position in terms of substance, subjects and scope. The second wave of rights moves that challenge beyond the mosaic of post-colonial experiences and into national and international Third Space constructions of human rights ideologies and objectives.

'Substance' refers to the content of a right. Third Generation Rights challenge the dominant, Western and Soviet ideologies on what constitutes a human right. They bring hybrid constructs to the fore; that is, rights that are interdependent on other subject areas that fall outside of the human rights matrix. The right to a clean and healthy environment, for example, is not included in the core human rights treaties but is enunciated in the Additional Protocol to the American Convention on Human Rights in the Area of Economic, Social and Cultural 
Rights; ${ }^{63}$ the African Charter on Human and Peoples' Rights; ${ }^{64}$ the United Nations Declaration on the Rights of Indigenous Peoples; ${ }^{65}$ and in 'soft law' documents including UN resolutions, ${ }^{66}$ reports, and the creation of a Special Procedures mandate on the impact on human rights caused by dumping of toxic and illicit waste. ${ }^{67}$ States from the Global South utilise the dominant human rights language and framework in order to bring the environment-a distinct subject area with its own institutions and mechanisms-into the human rights matrix. Many hybrid rights are framed as human rights owing to their impact on other human rights'; describing them in such a way ensures that the rights are viewed through a human rights prism. However, those so-called 'human rights' do not have a distinct or tangible substance that can be protected, nor do they have tangible victims whose 'rights' may be violated. The rights are immeasurable in terms of implementation. Yet, by framing the rights in this way they become part of the human rights discourse. States, then, have utilised the international Third Space to construct substantively hybrid rights that are informed by and also challenge the dominant ideology.

Another way in which Third Generation Rights challenge the dominant ideology on the substance of rights is through their increased focus on responsibilities and duties rather than on rights. As with Civil and Political Rights and Economic, Social and Cultural Rights, the substance of the first wave of Third Generation Rights focuses on the rights themselves. The right to self-determination is framed in such a way as to focus the substance upon the right:

All peoples have the right to self-determination. By virtue of that right they freely determine their political status and freely pursue their economic, social and cultural development. ${ }^{68}$

\footnotetext{
${ }^{63}$ Additional Protocol to the American Convention on Human Rights in the Area of Economic, Social and Cultural Rights (of San Salvador), 16 November 1999, A-52, Article 11.

${ }^{64}$ African Charter on Human and Peoples' Rights (Charter), 27 June 1981, 1520 UNTS 217, Article 24.

${ }^{65}$ GA Res 61/295, 2 October 2007, 'United Nations Declaration on the Rights of Indigenous Peoples'.

${ }^{66}$ See e.g. CHR Res 1999/23, UN Doc E/CN.4/1999/167, 26 April 1999, 100, 'Adverse effects of the illicit movement and dumping of toxic and dangerous products and wastes on the enjoyment of human rights'.

${ }^{67}$ CHR Res 1995/81, 8 March 1995, 'Adverse effects of the illicit movement and dumping of toxic and dangerous products and wastes on the enjoyment of human rights'.

${ }^{68}$ Common Article 1, International Covenant on Economic, Social and Cultural Rights (ICESCR), 16 December 1966, 993 UNTS 3 and International Covenant on Civil and Political Rights (ICCPR), 16 December 1966, 999 UNTS 171.
} 
The substance of that right focuses on the ways in which the right may be realised. However, the substance of the newer Third Generation Rights moves beyond focusing on granting individuals 'freedom from' state interference or even 'freedom to' make demands upon a state, both of which enable the substance of the right easily to be identified. Instead, the second wave Third Generation Rights focuses on responsibilities of states, making it more difficult to identify the tangible rights created by those obligations. The right to a democratic and equitable international order demonstrates hybridity in the right's substance. The resolution creating a Special Procedures mandate ${ }^{69}$ on the right to a democratic and equitable international order sets out 16 substantive aspects of the right. ${ }^{70}$ Some of the substantive aspects focus on the right while others focus on states' responsibilities, including: ' $\mathrm{t}$ ] he shared responsibility of the nations of the world for managing worldwide economic and social issues'; ' $;$ ' $t$ ] he promotion and consolidation of transparent, democratic, just and accountable international institutions in all areas of cooperation'; 72 and ' $t$ ] he promotion of equitable access to benefits from the international distribution of wealth through enhanced international cooperation, in particular in international economic, commercial and financial relations.' ${ }^{73}$ Hybridity here occurs through the substantive focus oscillating between rights and responsibilities, resulting in a construct that incorporates the polarised, and sometimes competing, ideologies from the Global North and South.

The debate on 'rights versus responsibilities' can clearly be seen in the differences between the regional human rights systems. The African Charter on Human and Peoples Rights ${ }^{74}$ was the first human rights treaty to set out responsibilities alongside rights. ${ }^{75}$ That way of viewing human rights is rooted in Africa's history and traditions and challenges the dominant, individual-focused ideology. The movement away from substantive focus on rights to the substantive focus on responsibilities shows the impact of hybridity and the construction of ideologies within the international Third Space. As states from the Global South have grown stronger, they have become more able to construct and promote a

\footnotetext{
${ }^{69}$ HRC Res 8/5, 18 June 2008, 'Promotion of a democratic and equitable international order'.

${ }^{70}$ Ibid, para. 3(a)-(p).

${ }^{71}$ Ibid, para. 3(p).

${ }^{72}$ Ibid, para. 3(g).

${ }^{73}$ Ibid, para. 3(n).

${ }^{74}$ African Charter on Human and Peoples' Rights (Charter), above n 64.

75 See generally U O Umozurike, 'The African Charter on Human and Peoples' Rights' (1983) 77 AJIL 902; Heyns, above n 7, 679.
} 
second wave of Third Generation Rights that better reflects hybrid norms and values that challenge the dominant ideology.

'Subjects' refers to who is bound by the human rights and to whom those obligations are owed. Third Generation Rights have expanded the subject of human rights both in terms of who, or what, are the rights holders and in terms of who owes the obligations. A main criticism of Third Generation Rights is that, unlike traditional rights, it is difficult to identify who would constitute a victim if one of those rights were to be violated. In many ways, the subjects of these newer rights are unclear, arguably owing to the focus being on responsibilities rather than rights. As such, Third Generation Rights have markedly expanded the subjects of rights.

The first wave of Third Generation Rights brought the idea of collective and peoples' rights to the fore. ${ }^{76}$ Whereas previously almost all rights ${ }^{77}$ focused on individuals, ${ }^{78}$ Third Generation Rights promote the idea of collective or peoples' rights. By focusing on rights such as to self-determination, permanent sovereignty over resources, and development, all of which may only be exercised by peoples, Third Generation Rights expanded who or what could be classed as rights holders. The second wave goes further, focusing on states as much as the people who collectively make up a nation or a country. The right to international solidarity and the right to a democratic and equitable order are aimed at states as an entity-rather than a group of people-and at groups of states, as they are collectives or groups of individuals. The Human Rights Council mandate on international solidarity, for example, requires the Independent Expert 'to promote and consolidate international assistance to developing countries in their endeavours in development and the promotion of conditions that make the full realization of all human rights possible. ${ }^{, 9}$ Although that responsibility discusses the individual as the rights holder, it is only in relation to secondary rights rather than to the right of international solidarity. It appears that states are the primary rights holders and that the realisation of the right to international solidarity will enable those rights holders-the states-to implement all human rights for individuals under their control. This extends the subjects of rights

\footnotetext{
${ }^{76}$ See generally Crawford, above $\mathrm{n} 10$.

${ }^{77}$ With few exceptions where the right belonged to an individual but could only be exercised as part of a collective or group.

${ }^{78}$ For a historical overview of collective, group and peoples' rights, see generally I Brownlie, 'The Rights of Peoples in Modern International Law', in Crawford, above n 10, 1-16.

${ }^{79}$ HRC Res 17/6, 6 July 2011, 'Mandate of the independent expert on human rights and international solidarity', para. 1(a).
} 
beyond individuals as rights holders, bringing states under the umbrella of the subjects to whom obligations are owed.

Expanding the subjects of rights from individuals to peoples and then to states themselves is a radical challenge to the dominant ideology. This is particularly true regarding Western notions of human rights, which focus solely on individuals and where some scholars and states at times still resist the framing of certain rights as 'people's rights'. Intertwining states and individuals as subjects and rights holders demonstrates hybridity-the construction of a new human rights ideology that is based upon, but also challenges, the dominant ideology while simultaneously incorporating norms and values of states from the Global South.

The second challenge that Third Generation Rights present to the dominant ideology's notion of the subjects of human rights is who owes the obligations contained within the rights. The newer rights expand the traditional understandings of who is bound by obligations. First, individuals and communities may be obligated to facilitate the rights of others. For example, the Declaration on the Right to Development says that '[a]ll human beings have a responsibility for development, individually and collectively'. ${ }^{80}$ This is a radical shift away from individuals solely being rights holders, and is rooted in African human rights ideologies. ${ }^{81}$ Secondly, states are made responsible for the behaviour of other states, which uses the traditional human rights framework by building upon foundations laid in the ICESCR ${ }^{82}$ whereby parties to that treaty are responsible for ensuring the core minimum obligations within states that have exhausted their maximum available resources. ${ }^{83}$ Although African and Asian states have demonstrated that this type of collective responsibility on states for human rights realisation within other states is part of their regional human rights ideology, the idea that states ought to be responsible for rights being realised within other states, as opposed to the narrower responsibility of violations being remedied, challenges the dominant, Western ideology on human rights. Thirdly, other actors may be bound by these obligations. Indeed, expansion of subjects is not just in relation to states and individuals. The right to international solidarity seeks to encourage 'more in-

\footnotetext{
${ }^{80}$ Ibid, Art. 7.

${ }^{81}$ Obinna Okere, above n 41.

${ }^{82}$ ICESCR, above n 68, Article 2(1).

${ }^{83}$ The Limburg Principles on the Implementation of the International Covenant on Economic, Social and Cultural Rights, UN Doc E/CN.4/1987/17, 8 January 1987, para. 30; Committee on Economic, Social and Cultural Rights, General Comment 3 (1990), UN Doc E/1991/23, 14 December 1990, para. 14.
} 
ternational actors [...] to take initiatives towards international solidarity, and to practice it in international relations. ${ }^{\text {, }}{ }^{2}$ This broad objective may lead to a range of international actors being bound by obligations under this right, with the Independent Expert insisting on the need to focus on relationships between states and international actors. ${ }^{85}$ Again, the international Third Space has been used to create a hybrid construct that expands the subjects of human rights in order to represent hybrid ideologies.

'Scope' refers to where the rights apply and the area where a state is bound by the obligations contained within a right. Traditional rights place obligations upon states to respect, protect and fulfil the right. ${ }^{86}$ Generally, the scope of those rights exists within territory where a state exercises control, although there are some instances of extraterritorial applicability. ${ }^{87}$ Third Generation Rights extend the scope of rights owing to their extension of the substance and subjects of rights. The right to international solidarity, for example, seeks to place responsibility on states for ensuring sufficient redistribution of wealth to enable other states to have sufficient resources for human rights to be realised within their territories. That scope goes beyond traditional territorial and extraterritorial application of human rights obligations. Instead, human rights become a collective responsibility of all states insofar as there is a global responsibility to ensure that all states are able to implement human rights.

Throughout his reports, the Independent Expert on the right to international solidarity emphasises that it places a responsibility on states:

International cooperation and solidarity are based on the concept of shared responsibility. The notion of common but differentiated responsibilities has potential value in the development of a right of peoples and individuals to solidarity. ${ }^{88}$

\footnotetext{
${ }^{84} \mathrm{HRC} 4^{\text {th }}$ Session, Report of the independent expert on human rights and international solidarity, Rudi Muhammad Rizki, UN Doc A/HRC/4/8, 7 February 2007, para. 4.

${ }^{85}$ Ibid, para. 11.

${ }^{86}$ See generally P Alston \& G Quinn, 'The Nature and Scope of States Parties' Obligations under the International Covenant on Economic, Social and Cultural Rights', (1987) 9(2) Human Right Quarterly 156.

${ }^{87}$ See e.g. Human Rights Committee, General Comment No 31 (2004), UN Doc CCPR/C/21/Rev.1/Add.13, 26 May 2004; Legal Consequences of the Construction of a Wall in the Occupied Palestinian Territory, ICJ Reports 2004, p 136.

${ }^{88} \mathrm{HRC} 12^{\text {th }}$ Session, Report of the independent expert on human rights and international solidarity, Rudi Muhammad Rizki, UN Doc A/HRC/12/27, 22 July 2009, para. 42.
} 
The concept of 'shared responsibility' for ensuring that rights are able to be realised within other countries' jurisdiction results in the scope of human rights being extended beyond traditional understanding of where states owe their obligations. The ideology underpinning shared responsibility goes beyond the postcolonial idea that former imperial powers owe duties to former colonies, and instead is rooted in African ideologies on responsibilities for other states and in post-Marxist discourses on global inequalities. Indeed, drawing on what appears to be post-Marxist theories the Independent Expert emphasises that 'the duty of solidarity [is] an imperative prerequisite of globalization. ${ }^{89}$ Bringing these hybrid ideologies into the human rights system using a human rights framework enables states from the Global South effectively to challenge the dominant understanding of the scope of human rights by requiring states to ensure the primary right beyond their own jurisdiction in order to enable realisation of all other human rights within other states' territories. The collective responsibility that Third Generation Rights place on states results in the scope extending to the transnational and international levels. The responsibilities placed on states transcend national borders and are dependent on matters occurring at the transnational and international levels.

\section{Is there room for hybrid constructs within international human rights law?}

International human rights law is going through another evolutionary cycle with development of new rights and, more broadly, the way that human rights operate at the international level. Those changes are based on hybrid norms and values, which give rise to hybrid rights that move beyond post-colonialism and challenge the dominant human rights ideologies. Although hybrid rights are at various stages in their development, with some still embryonic, they have significant support from states across four of the five regional groups as well as the two largest political blocs at the UN. Aspects of these hybrid rights, arguably, are incompatible with, or overly expand, the human rights matrix that was largely created by Western states. However, the West's current approach of claiming that hybrid rights are not 'rights' has failed to impact their creation, promotion and development within the international arena. Therefore, it would be better, from both the theoretical and practical perspectives, that these rights are explored

$\overline{89} 4^{\text {th }}$ Session Report of Rudi Muhammad Rizki, above n 84, para. 48. 
and discussed at the theoretical as well as practical level in order to ensure that the evolutionary process within the human rights system occurs in a more systematic and less ad hoc manner. Understanding the theories underpinning hybrid rights will enable those rights to develop in a way that enhances, rather than undermines, the international human rights system.

Dominance of developing and decolonised states, alongside their allies within political blocs, at the UN results in large numbers of states promoting or supporting new Third Generation Rights. Even though not all states from Africa, Asia, Eastern Europe, and Latin America and the Caribbean support all of the rights, the cross-regional alliances through the Non-Aligned Movement and the Organisation of Islamic Cooperation mean that there are many potential allies available to support new constructions of hybrid rights. Indeed, it is this hybridity that enables each right to stem from subgroups of states that share common values and cultures, or who use the international Third Space to intertwine their national human rights ideologies and construct new rights based on those hybrid norms. The sheer number of states involved with constructing these new rights indicates that they will eventually be embedded within the human rights matrix, regardless of their substance, through votes on non-binding international 'soft law' instruments that are later used as 'proof' of the right's existence.

Hybrid rights, from a realist perspective, are a method for states to challenge and assert their collective strength against the Global North. The objectives behind the rights might be as much about anti-West political aims as about human rights. Indeed, among the states promoting and supporting hybrid rights are known human rights abusers, as well as states with autocratic or dictatorial regimes. A realist perspective highlights that those states' motives cannot purely, or even largely, be concerned with the realisation of human rights, owing to their own poor records for implementing such rights. Arguably, those states are using hybrid rights to dilute the system through rights expansion, which reduces the available resources that can be devoted to any one right. Similarly, the system is undermined by the expansion of what constitutes a right. Hybrid rights are then used to challenge dominant states by shifting the focus away from protecting tangible victims from tangible violations, instead using the human rights matrix to attack Western states for broader concerns relating to global politics and economics.

Although some states might be using the rights as a method to weaken, dilute or undermine the human rights system, from an idealist perspective there are strong ideological reasons for the construction of hybrid rights. The new rights move beyond post-colonial discourses and represent hybrid ideologies, 
norms, values and cultures. Indeed, and as social constructivists might insist, the new rights represent heterogeneous ideologies and values that were not represented during the initial creation and development of international human rights law. While they may take away finite resources for other rights, they are also expanding the system and the way in which rights operate in order to make international human rights law more relevant to more states. The rights provide vehicles for realising other rights, and bring into the arena subject areas that necessarily impact on rights. They also seek to ensure that responsibility for rights implementation falls onto the international community as a whole. While this may provide a smokescreen for abusers or allow states to avoid responsibility for their own obligations, it also reflects the difficulties, as set out by post-colonialists and post-Marxist theorists, of imposing Western constructs on weaker and less developed states.

Regardless of the motivations for state behaviour in creating and promoting hybrid rights-in-depth analysis of which goes beyond the scope of this articlethey are a significant development of the international human rights system. The methods of creating these new rights, however, make that they are not yet enshrined in international human rights law to the same extent as traditional rights. The West's lack of support for many hybrid rights means that they cannot be created through traditional methods of treaties and customary international law. States from the Global North simply would not consent to be bound by such laws. Countries currently seeking to include their concepts of 'rights' within the international framework instead promote these newer rights through resolutions ${ }^{90}$ and decisions ${ }^{91}$ at UN bodies and by creating new Special Procedures mandates. ${ }^{92}$ It is easier to secure a vote on resolutions, decisions, and new mandatesespecially at the UN Human Rights Council where the Non-Aligned Movement

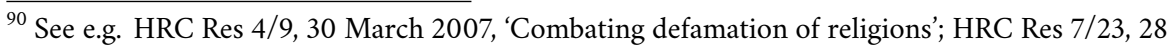
March 2008, 'Human rights and climate change'; HRC Res 8/5, 18 June 2008, 'Promotion of a democratic and equitable international order'; and HRC 9/2, 24 September 2008, 'Human rights and international solidarity'.

${ }^{91}$ See e.g. HRC Decision 1/107, 30 June 2006, UN Doc A/HRC/DEC/1/107, 'Incitement to racial and religious hatred and the promotion of tolerance'; HRC Decision 2/105, 27 November 2006, UN Doc A/HRC/DEC/2/105, 'Right to the truth'; HRC Decision 4/102, 23 March 2007, UN Doc A/HRC/DEC/4/102, 'Transitional justice'.

${ }^{92}$ See e.g. HRC Res 17/6, 6 July 2011, 'Mandate of the independent expert on human rights and international solidarity;' HRC Res 18/6, 13 October 2011, 'Promotion of a Democratic and Equitable International Order'; HRC Res 18/7, 13 October 2011, 'Promotion of Truth, Justice, Reparation and Guarantees on Non-Recurrence'.
} 
and the Organisation of Islamic Cooperation dominate proceedings ${ }^{93}$-than to secure agreement on a new international human rights treaty. Those methods are then used as 'soft law' to demonstrate the existence of a 'right', as occurred with the right to water. ${ }^{94}$ It is likely that the rights will continue to develop and that, despite the lack of treaties and custom enshrining many hybrid rights, states will be bound by the obligations contained therein.

The West's continued opposition to Third Generation Rights means that Western states are unable to engage with, and thus influence, their development. By allowing these rights to be constructed only by states from the Global South, the West is perpetuating their potential abuse. It enables states seeking to divert resources away from their own misconduct to do so, by overburdening the system and shifting the focus away from ongoing abuses within their own territories. Rather than dismissing these new rights, it would be better to understand the ideologies underpinning these rights in order to understand how they will affect the human rights system. Embracing hybridity as the current method of developing international human rights law will provide an opportunity to ensure that hybrid rights develop and are then implemented in such a way as to enable better rights protection and promotion across the world. In that way, the human right system will expand without being significantly undermined or diluted by current developments.

The human rights community, particularly in the West, must make room for hybridity theories and processes, even if it criticises some hybrid aspects of the second wave of Third Generation Rights. The lessons that may be learnt from classicists and political scientists is that top-down imposition of ideologies through globalisation or universalism do not work, while postcolonial or cultural relativist discourses fail to adequately address the issues raised within the international arena. There must be room for ideologies that challenge the dominant, through the construction of alternative narratives and discourses based on heterogeneous norms values and cultures, as well as the experiences and narratives of weaker states operating within the international arena. Caution must be exercised, however, in allowing too much room for hybrid constructs that seek to undermine rather than improve the international human rights system and, more generally, international law. Hybridity must not be allowed to be

\footnotetext{
${ }^{93}$ See generally Freedman, above $n$ 26, 122-128.

${ }^{94}$ GA Res 64/292, 3 August 2010, 'The Human Right to Water and Sanitation'; cf. UN Department of Public Information, 'General Assembly Adopts Resolution Recognizing Access to Clean Water, Sanitation as Human Right', 28 July 2010, <http://www.un.org/Ne ws/Press/docs/2010/ga10967.doc.htm> [accessed 15 October 2013].
} 
used as a smokescreen to mask malignant intentions, particularly towards human rights. There is a need to understand the development of new rights based on hybrid constructs that move beyond post-colonial discourses and give a voice to states that were previously unable to promote their ideologies on human rights. However, human rights scholars must engage further with hybridity theories and processes in order to identify when a right is hybrid and when the so-called hybrid aspects are simply a way of seeking to undermine the human rights system. 